[The Version of Record of this manuscript has been published and is available in ANNALS OF SCIENCE, vol. 78, no. 4, https://www.tandfonline.com/doi/full/10.1080/00033790.2021.1965216]

\title{
Guillaume des Moustiers' treatise on the armillary instrument (1264) and the practice of astronomical observation in medieval Europe
}

C. Philipp E. Nothaft

Trinity College Dublin, Dublin, Ireland

nothaftc@tcd.ie

\begin{abstract}
This article is devoted to a thirteenth-century Latin text on how to construct, set up, and use a version of the so-called armillary instrument (instrumentum armillarum), which was first described in Ptolemy's Almagest as a tool for measuring ecliptic coordinates. Written in 1264 by Guillaume des Moustiers, bishop of Laon, this hitherto unstudied Tractatus super armillas survives in a single manuscript, where it is accompanied by a copious set of glosses. The text and its glosses jointly offer an unusually detailed account of the instrument's material aspects and methods of assembly. In addition, they reflect a keen awareness of the potential sources of error that may arise in the context of astronomical observation, while making suggestions on how these errors may be minimized or avoided. The Tractatus super armillas accordingly is a valuable source on the observational side of medieval European astronomy, which has often been minimized in modern historical accounts.
\end{abstract}


Keywords: medieval astronomy; thirteenth-century; astronomical observation; astronomical instruments; armillary instrument; Ptolemy 


\section{Introduction}

Modern historians writing about the discipline of astronomy in medieval Europe have generally found that its practice rarely involved any empirical measurements of celestial positions, and that such measurements played no discernible role in its development prior to the fifteenth or even sixteenth century. ${ }^{1}$ Although it may not be possible to overturn this verdict completely, the study of texts, drawings, and marginalia encountered in Latin manuscripts of the eleventh to fourteenth centuries is certainly capable of yielding data in favour of a more nuanced picture. In the present article, I intend to demonstrate one area where such revision seems possible, by discussing a previously neglected thirteenth-century text on how to construct, set up, and employ a so-called armillary instrument (instrumentum armillarum) in the measurement of celestial coordinates. As I hope to show, this unpublished Tractatus super armillas, written in 1264 by Guillaume des Moustiers, bishop of Laon, sheds an intriguing light on the observational practices of the second half of the thirteenth century. Together with the copious annotations that adorn the text in the only known manuscript, the

\footnotetext{
${ }^{1}$ Emblematic of this position are the numerous publications on this subject by Emmanuel Poulle, who held that 'l'astronomie médiévale n'est presque jamais une astronomie d'observation' and that '[1]es relations ou comptes rendus d'observations sont rarissimes'. The quotes appear in Poulle, 'Les instruments astronomiques de l'Occident latin aux $\mathrm{XI}^{\mathrm{e}}$ et XII ${ }^{\mathrm{e}}$ siècles', Cahiers de civilisation médiévale, 15 (1972), $27-40$ (p. 40). Poulle, 'L'astronomie du Moyen Âge et ses instruments', Annali dell'Istituto e Museo di Storia della Scienza di Firenze, 6, no. 2 (1981), 3-16 (p. 7). See also Poulle, Les sources astronomiques (textes, tables, instruments) (Turnhout: Brepols, 1981); Poulle, Les instruments astronomiques du Moyen Âge (Paris: Brieux, 1983); Poulle, 'L'instrumentation astronomique médiévale', in Observer, lire, écrire, le ciel au Moyen Âge: actes du colloque d'Orléans, 22-23 avril 1989, ed. by Bernard Ribémont (Paris: Klincksieck, 1991), pp. 253-81; Poulle, 'L'astronomie latine au XII ${ }^{\mathrm{e}}$ siècle', in Cieli e terre nei secoli XI-XII: orizzonti, percezioni, rapporti; atti della tredicesima Settimana internazionale di studio Mendola, 22-26 agosto 1995 (Milan: Vita e pensiero, 1998), pp. 75-88; Poulle, 'Mesures et astronomie au Moyen Âge', Micrologus, 19 (2011), 73-87; John D. North, 'Astronomy and Astrology', in The Cambridge History of Science, vol. 2, Medieval Science, ed. by David C. Lindberg and Michael Shank (Cambridge: Cambridge University Press, 2013), pp. 456-84. On the wider question of observation in medieval science, see Katharine Park, 'Observation in the Margins, 500-1500', in Histories of Scientific Observation, ed. by Lorraine Daston and Elizabeth Lunbeck (Chicago: The University of Chicago Press, 2011), pp. 15-44.
} 
Tractatus documents a clear awareness of some of the practical difficulties that a user of the instrument in question would have confronted as well as a corresponding intention to find ways to compensate against observational error. Owing to these and other traits, the Tractatus super armillas makes for an important new source on the status of instruments and their observational uses in medieval astronomy. Furthermore, it helps us mend a gap in our knowledge of the armillary instrument in medieval Europe, which thus far has been restricted by a dearth of concrete evidence. ${ }^{2}$

\section{The armillary instrument in high medieval Europe}

The instrument whose thirteenth-century manifestations will concern us below makes its first recorded appearance at the beginning of Book V of Ptolemy's Almagest, where the Alexandrian astronomer describes an astrolabon organon ('instrument for taking stars') for the measurement of ecliptic coordinates (longitudes and latitudes). ${ }^{3}$ This astrolabon, which became an instrumentum armillarum ('instrument made of rings') in Gerard of Cremona's twelfth-century Arabic-to-Latin translation of the Almagest, must be cleanly distinguished both from the ordinary planispheric astrolabe and from the various types of armillary spheres

\footnotetext{
${ }^{2}$ As noted by Poulle, 'L'astronomie du Moyen Âge', p. 10, when he referred to the armillary instrument as 'un instrument dont l'existence au moyen âge est plus présumée que formellement connue'.

${ }^{3}$ For an English translation of the relevant chapter, see G. J. Toomer, trans., Ptolemy's Almagest, rev. ed. (Princeton, NJ: Princeton University Press, 1998), pp. 217-19. For Gerard of Cremona's Latin translation, see Ptolemy, Almagestum (Venice: Liechtenstein, 1515), fols. 46v-47r.
} 
ancient and medieval astronomers used for computational or didactic purposes. ${ }^{4}$ In contrast to the latter, Ptolemy's armillary instrument was geared strictly towards observational uses. ${ }^{5}$

[Figure 1 near here]

To this end, he described an apparatus made up of six concentric rings, the outermost of which (6 in Fig. 1) is fixed in the plane of the meridian. ${ }^{6}$ The two points on this ring that correspond to the positions of the celestial north and south poles (relative to one's local geographic latitude) are perforated and equipped with cylindrical pivots (d), which will enable the inner nest of five rings to be turned in accordance with the diurnal revolution of the firmament. Turning immediately on these pivots is a ring that represents the solstitial

\footnotetext{
${ }^{4}$ General histories of the armillary sphere were written by Friedrich Nolte, Die Armillarsphäre (Erlangen: Mencke, 1922), whose focus is on the Islamic world, and Mercè Comes, Historia de la esfera armilar: su desarrollo en las diferentes culturas (Madrid: Fundacíon Juanelo Turriano; Universitat de Barcelona, 2012), which is global in outlook, but rather terse in its coverage of the Latin Middle Ages. Sources from medieval Spain and North Africa are covered in Julio Samsó, On Both Sides of the Strait of Gibraltar: Studies in the History of Medieval Astronomy in the Iberian Peninsula and the Maghrib (Leiden: Brill, 2020), pp. 352-72.

${ }^{5}$ For discussions of the instrument and its uses, see A. Rome, 'L'astrolabe et le météoroscope d'après le Commentaire de Pappus sur le $5^{\mathrm{e}}$ livre de 1'Almageste', Annales de la Société scientifique de Bruxelles, ser. A, 47 (1927), 77-102 (pp. 77-90); D. R. Dicks, ‘Ancient Astronomical Instruments’, Journal of the British Astronomical Association, 64 (1954), 77-85 (pp. 81-83); Derek J. Price, 'Precision Instruments: To 1500', in A History of Technology, vol. 3, From the Renaissance to the Industrial Revolution c.1500-c.1700, ed. by Charles Singer, E. J. Holmyard, A. R. Hall, and Trevor I. Williams (Oxford: Oxford University Press, 1957), pp. 582619 (pp. 591-92); Jarosław Włodarczyk, 'Observing with the Armillary Astrolabe', Journal for the History of Astronomy, 18 (1987), 173-95; James Evans, The History \& Practice of Ancient Astronomy (New York: Oxford University Press, 1998), pp. 251-56; Evans, 'The Material Culture of Greek Astronomy', Journal for the History of Astronomy, 30 (1999), 237-307 (pp. 277-79); Dennis W. Duke, 'Ptolemy's Instruments', in
} Hellenistic Astronomy: The Science in Its Contexts, ed. by Alan C. Bowen and Francesca Rochberg (Leiden: Brill, 2020), pp. 246-58 (pp. 250-52).

\footnotetext{
${ }^{6}$ Most descriptions in the modern literature follow Rome (note 5) in imagining this ring as turning inside another meridional ring, allowing the instrument to be adjusted for geographic latitude. This, however, is not part of Ptolemy's original description.
} 
colure (4). It comes with its own set of pivots (e), whose positions on the ring correspond to the ecliptic poles. They protrude on both sides, making it possible to attach further rings on the outside (5) and inside (2). The ecliptic itself is represented by a graduated ring (3) joined orthogonally to the solstitial colure. This arrangement allows the two rings rotating outside and inside the solstitial colure (5 and 2) to mark the ecliptic longitudes of different celestial bodies. The inner ring (2) is itself graduated to show degrees of ecliptic latitude. Fitted inside it is a thinner ring (1), which moves freely along its concave inner surface. It holds two perforated sighting vanes (b) at opposite points, making it possible to read the latitudes of celestial objects off the scale engraved on the surrounding ring.

Perhaps the earliest available hint that astronomers in medieval Europe had begun to build their own versions of this instrument and employ it for observational purposes comes from a list of stellar coordinates drawn up in Paris in the year 1246 by a certain John of London. Most extant copies of this list allege that the ecliptic coordinates it records were 'verified' with an armillary instrument (verificata per instrumentum armillarum). ${ }^{7}$ John of London himself made the same claim in a letter he addressed to an individual named $R$. de Guedingue, in which he mentions a subjoined star list 'that I have verified with rings

\footnotetext{
${ }^{7}$ This source was edited and discussed in Paul Kunitzsch, Typen von Sternverzeichnissen in astronomischen Handschriften des zehnten bis vierzehnten Jahrhunderts (Wiesbaden: Harrassowitz, 1966), pp. 39-46. See also Emmanuel Poulle, 'Peut-on dater les astrolabes médiévaux?', Revue d'histoire des sciences et de leurs applications, 9 (1956), 301-22 (pp. 313-15); Paul Kunitzsch, 'John of London and His Unknown Arabic Source', Journal for the History of Astronomy, 17 (1986), 51-57. A different version is edited in Fritz S. Pedersen, The Toledan Tables, 4 vols. (Copenhagen: Reitzel, 2002), IV, pp. 1502-1504 (LA15). John's list was also incorporated into Pierre de Maricourt, Nova compositio astrolabii particularis, c. 15, ed. by Ron B. Thomson, in Petrus Peregrinus de Maricourt: Opera, ed. by Loris Sturlese and Ron B. Thomson (Pisa: Scuola Normale Superiore, 1995), pp. 150-53. A reduced version of 31 stars frequently appears as part of a popular treatise on astrolabe construction falsely attributed to Māshā'allāh. See Pseudo-Māshā'allāh, On the Astrolabe, vol. 3, Lists of Stars, ed. by Ron B. Thomson (version 1.5), pp. 26-41 [https://hdl.handle.net/11244/14221].
} 
[armillae] in Paris'. ${ }^{8}$ Elsewhere in the same letter, he speaks of the possibility of using rings to find the longitudes of the planets at one's local meridian and thereby obtain radices (starting positions) for computational tables. ${ }^{9}$

The ecliptic longitudes in John of London's list do not reflect a uniform increase relative to the star catalogue contained in the Almagest and even the latitudes, which normally remain constant, exhibit variations vis-à-vis the Ptolemaic ones. While this would seem to lend support to the idea that John of London derived these coordinates via observation, ${ }^{10}$ other features of his star list raise doubts about the nature of John's 'verification'. According to Elly Dekker, the ecliptic longitudes are adequate for the middle of the twelfth century and may have been derived, not through strict observation, but from the star-pointers on an existing astrolabe, or perhaps from a pre-existing Islamic list. ${ }^{11}$

Far more compelling evidence of Ptolemy's instrument being used in Paris comes from an extended record of observations in MS Oxford, Corpus Christi College, 144, fols. 97r-98v (s. XIV ${ }^{\text {in }}$ ), which lists more than 70 planetary longitudes (and two latitudes) across

\footnotetext{
${ }^{8}$ MS Paris, Bibliothèque nationale de France, lat. 7413/II, fols. 19va-21ra (s. XIII $\left.{ }^{\mathrm{ex}}\right)$, at fol. 20vb: 'Tabulam autem stellarum fixarum in astrolabio ponendarum, quam ego Parisius per armillas verificavi, transcriptam vobis transmitto'. The letter also appears in MSS Vatican City, Biblioteca Apostolica Vaticana, Pal. lat. 1340, fols. 84rb-85rb (s. XV ${ }^{\mathrm{med}}$ ); Oxford, Bodleian Library, Digby 168, fol. 67ra (incomplete, end only; s. XIV [before 1372]). The transcription of the Paris copy in M(onsieur) Fontès, 'Le manuscrit de Jean de Londres', Bulletin de l'Académie des sciences, inscriptions et belles-lettres de Toulouse, 1 (1897-98), 146-60 (pp. 148-55), is severely deficient. I am currently preparing a new critical edition and English translation of the text.

${ }^{9}$ MS Paris, Bibliothèque nationale de France, lat. 7413/II, fol. 20rb: 'Sed si voluerimus facere tabulas secundum longitudinem civitatis nostre, sciamus per armillas loca omnium planetarum ad meridiem nostrum, et sic sciemus ponere radices mediorum motuum in tabulis nostris'.

${ }^{10}$ See the remark in Kunitzsch, Typen (note 7), p. 39.

${ }^{11}$ Elly Dekker, 'A Close Look at Two Astrolabes and Their Star Tables', in Sic Itur ad Astra: Studien zur Geschichte der Mathematik und Naturwissenschaften, ed. by Menso Folkerts and Richard Lorch (Wiesbaden: Harrassowitz, 2000), pp. 177-215 (pp. 191-94, 214-15).
} 
45 dates in the years 1312 to $1315 .^{12}$ In the case of a conjunction of Jupiter and Mars, observed during the night of 18/19 February, the astronomer in question speaks of having ascertained its degree $\left(25 ; 30^{\circ} \mathrm{Gemini}\right)$ 'by looking at both rings' (per considerationem utriusque armille). ${ }^{13}$ The two rings in question were presumably those that revolved around the poles of the ecliptic in Ptolemy's instrument (2 and 5 in Fig. 1). Of these, the outer ring would have been moved to the longitude of a known star and then brought into alignment with its observed position - thereby orienting the ecliptic ring —, while the inner one would have been moved to align with the conjunct planets. This modus operandi is indeed strongly suggested by the astronomer's habit of prefacing his observed planetary positions with the longitude of a bright star ( $\alpha \mathrm{Tau}, \alpha \mathrm{Aql}, \alpha \mathrm{Leo}$, or $\alpha \mathrm{CMa})$ together with the corresponding degree at mid-heaven (indicated by the intersection of rings 6 and 3 in Fig. 1), which was a way of noting the local time.

There is reason to believe that planetary observations of this nature had been conducted in Paris for some time prior to 1312. The introduction to an Almanach planetarum composed by William of Saint-Cloud in 1292 describes several observations of the Moon and the three superior planets, which inspired the author to make certain adjustments to his computational tables (the Tables of Toulouse). In one instance, William tells us he determined the relative positions of Mars and the Moon with the help of 'rings' (per armillas), which happened during the night of $1 / 2$ July $1292 .{ }^{14}$ That astronomers in William's

\footnotetext{
${ }^{12}$ See Lynn Thorndike, 'Astronomical Observations at Paris from 1312 to 1315', Isis, 38 (1948), 200-05, who includes a transcription of the record in question. I have checked Thorndike's transcription against the manuscript and found it to be generally reliable. The source was also discussed by Ernst Zinner, 'Magister Alard von Diest und die Pariser Beobachtungen von 1312-15', Isis, 42 (1951), 38-40, who argues that the observing astronomer was Alard of Diest.

${ }^{13}$ Thorndike, 'Astronomical Observations' (note 12), p. 204a.

${ }^{14}$ See the edition and translation of $\$ 20$ in Fritz S. Pedersen, 'William of Saint-Cloud: Almanach Planetarum; An Edition of the Canons, A Few Samples from the Tables, and a Foray into the Numbers', Cahiers de l'Institut du Moyen Âge Grec et Latin, 83 (2014), 1-133 (pp. 16, 43).
} 
time had already gained some experience in using the armillary instrument, to the point that they could comment in some detail on its methods of construction and the problems that may arise during its practical application, is one of the conclusions one may take away from the Tractatus super armillas, the text to be discussed in what follows.

\section{The text and its manuscript}

Credit for having drawn attention to the previously forgotten existence of the Tractatus super armillas must go to Henry Zepeda, who included some remarks on it in his 2018 edition of the Almagesti minor. ${ }^{15}$ The latter work originated in Latin Europe in the late twelfth or early thirteenth century (before 1220) and may be described as a rephrased version of the first six books of Ptolemy's Almagest, albeit one that introduces information from other sources, especially the canons to al-Battānī's $S \grave{a} b i$ ' Zīj (in Plato of Tivoli’s twelfth-century Latin translation), and presents the result in a 'Euclidian' format based on propositions and proofs. This format proved rather successful, as seen from the fact that the Almagesti minor still survives in at least 23 full copies. ${ }^{16}$ Its reception was further amplified by the circulation of smaller extracts, including one set that united different passages on astronomical instruments. This text, which is preserved in at least 11 manuscripts, opens with an account of the armillary instrument, hence the incipit Queruntur primum due armille... ${ }^{17}$

As Zepeda already correctly noted, the Almagesti minor's description of the armillary instrument was incorporated into a separate Latin treatise written in 1264 and credited to Guillaume des Moustiers, bishop of Laon. This Tractatus in compositione et opere

\footnotetext{
${ }^{15}$ Henry Zepeda, The First Latin Treatise on Ptolemy's Astronomy: The Almagesti minor (c. 1200) (Turnhout: Brepols, 2018), pp. 84-85.

${ }^{16}$ See Zepeda, The First Latin Treatise (note 15), pp. 47-70.

${ }^{17}$ Zepeda, The First Latin Treatise (note 15), pp. 71-75. A stand-alone copy of the chapter on the armillary instrument, together with extensive glosses, appears in MS Milan, Biblioteca Ambrosiana, R. 47 sup., fols. 118v-119r (s. XIII/XIV not noted by Zepeda).
} 
armillarum ad inveniendum loca planetarum et aliarum stellarum ('Treatise on the composition and use of rings to find the places of the planets and other stars'), or simply Tractatus super armillas ('Treatise on the rings'), is currently known only from MS Fermo, Biblioteca civica 'Romolo Spezioli', 85 (hereafter cited as $F$ ), which is an anthology (135 fols.) of astrological and astronomical works. The first 113 leaves of this collection, which conclude with our Tractatus (fols. 111r-113v), were copied by a single hand between 1264 and $1293 .{ }^{18}$ Some of the other texts in this section point to a Parisian origin, as is the case with the excerpts from a Parisian astrolabe treatise on fol. $75 \mathrm{va}-76 \mathrm{vb}$ and an unknown text on a horary quadrant on fol. 95ra-va, with reference to the latitude of Paris. ${ }^{19}$ David Juste has discovered another Parisian feature on fol. 79va, where the treatise De utilitatibus astrolabii is attributed to Gilebertus (i.e., Gerbert of Aurillac). The only other known copy of the text with this precise attribution is MS Paris, Bibliothèque nationale de France, lat. 16652, fols. 14v-21v. This codex formerly belonged to Richard de Fournival, chancellor of Amiens cathedral, and came to Paris soon after his death in $1260 .{ }^{20}$

\footnotetext{
${ }^{18}$ For descriptions, see Serafino Prete, I codici della Biblioteca Comunale di Fermo: catalogo (Florence: Olschki, 1960), pp. 118-21; Pedersen, The Toledan Tables (note 7), I, p. 115; David Juste, 'MS Fermo, Biblioteca Comunale, 85 (update: 20.04.2020)', Ptolemaeus Arabus et Latinus. Manuscripts <http://ptolemaeus.badw.de/ms/235> [accessed 21 July 2021].

${ }^{19} F$, fol. 76ra: 'Si ergo vis scire ortum alicuius signi in nostro climate, in Parisiensi scilicet, pone...' $F$, fol. 95ra: 'Verbi gratia, latitudo Parisius vel alterius loci in $7^{\circ}$ climate est 48 graduum. Cum ergo eris Parisius vel alibi in tali loco cuius talis est latitudo, scilicet 48 graduum, fac...' The excerpts on the astrolabe stem from an unpublished text beginning Quelibet ars suum habet artificem..., different recensions of which are found in MSS Erfurt, Universitäts- und Forschungsbibliothek, Dep. Erf. CA $4^{\circ}$ 352, fols. 110r-112r (s. XIII ${ }^{1 / 2}$ ); Oxford, BodLib, Ashmole 361, fols. 35ra-41vb (s. XIV' ${ }^{\text {med }}$ ). See Paul Kunitzsch, 'Glossar der arabischen Fachausdrücke in der mittelalterlichen europäischen Astrolabliteratur', Nachrichten der Akademie der Wissenschaften in Göttingen, phil.-hist. Kl., Jg. 1982, Nr. 11, pp. 459-571 (pp. 506-507), commenting on the Oxford manuscript. ${ }^{20}$ See Juste's description of the Fermo MS cited in n. 18, and Richard H. Rouse, 'Manuscripts Belonging to Richard de Fournival', in idem and Mary A. Rouse, Bound Fast with Letters: Medieval Writers, Readers, and Texts (Notre Dame, IN: University of Notre Dame Press, 2013), pp. 115-38 (pp. 128-29).
} 
The subheadings included in the Fermo copy of the Tractatus super armillas divide the text into three parts, of which the first shows how to assemble the rotatable nest of five inner rings (1-5 in Fig. 1). A large part of this section is taken up with the manufacturing techniques that can be used to ensure the innermost ring (1) fits snugly inside the graduated ring used for measuring longitudes (2). The second part explains how to set up the meridional ring (6) and describes the instrument's material support in the shape of a column-pedestal combination. The third part, finally, offers a brief account of how to apply the instrument in observations.

Authorship and date are attested firmly and clearly in an extended colophon, which states that Guillaume, bishop of Laon, wrote this 'Treatise on the rings' in the Year of the Lord 1264 (1263 perfecto), on 10 November, the day before the feast of St Martin. ${ }^{21}$ The colophon goes on to note that the same year had been the occasion of many planetary conjunctions as well as 'many impressions', which presumably refers to astro-meteorological effects. It further mentions the appearance of a comet in the sign of Cancer, which was indeed widely noticed and commented upon by contemporary Latin writers. ${ }^{22} \mathrm{We}$ are told that the tail of this comet reached a longitudinal extent of $90^{\circ}$, pointing in the direction of Aries. ${ }^{23}$ In the following year, Jupiter and Saturn were in conjunction in the sign of Gemini. From this

\footnotetext{
${ }^{21} F$, fol. 113v: 'Explicit tractatus Guillelmi episcopi Laudunensis super armillas scriptus anno domini 1263 perfecto. Et de inperfecto menses 10, dies 10, cuius finis fuit vigilia beati Martini episcopi, quod est 4 idus Novembris. Et in illo anno imperfecto fuerunt multe coniunctiones planetarum et multe impressiones. Et apparuit una de cometis in Cancro, que "dominus ascone" appellatur, a qua exibat radius in longitudine 90 graduum, que exivit a zodiaco gradiens contra stellas et signorum successionem ultra Arietis regionem. In anno sequento fuit coniunctio Saturni et Iovis in signo humano, in regione videlicet Geminorum [ms. Grecorum]'. ${ }^{22}$ Lynn Thorndike, Latin Treatises on Comets between 1238 and 1368 A.D (Chicago: University of Chicago Press, 1950), pp. 87-195. In addition to the sources mentioned and/or edited there (Giles of Lessines, Gerard of Feltre, Roger Bacon, Thierry de Vaucouleurs), see Restoro d'Arezzo, La composizione del mondo II.7.5, ed. by Alberto Morino (Parma: Fondazione Pietro Bembo; Guanda, 1997), pp. 299-300.

${ }^{23}$ That the comet's tail at one point stretched across one-quarter of the entire hemisphere was also recorded by Gerard of Feltre, Summa de astris 1.23.2, ed. Thorndike (note 22), p. 193.
} 
retrospective remark about the year 1265, it would seem that the colophon was only added subsequent to the Tractatus's original composition.

Guillaume des Moustiers served as bishop of Laon from 1262 to 1269. His motivations for diverting time from his pastoral duties to compose a work on an astronomical instrument must remain a matter of speculation. ${ }^{24}$ What is clear, at any rate, is that he had before him the relevant section of the Almagesti minor, whether as part of a full copy or in the form of an excerpt. His own account of how to build and use the armillary instrument draws on the wording of this source, but adds considerably to its substance, creating a text three times its length (approx. 1800 words).

The scribe responsible for the Fermo copy of Guillaume's Tractatus was very generous in leaving space for additions in the margins. On the first four pages (fols. 110r$111 \mathrm{v})$, the column of main text only takes up one-third of the available width, allowing for glosses to appear on both sides. A total of 25 glosses accompany the text in this manuscript, only one of which is not relevant to its actual content. Most of the remaining ones recapitulate, elucidate, or elaborate on the information presented in the main text. Some of them appear to have originated as commentaries on drawings that depicted different components of the instrument, but which were not carried over into the Fermo copy. This is especially clear on fol. 112r, where the main text is shifted to the left and changes its linewidth several times before returning to the centre-column of the page. The resulting layout leaves a blank space in the middle, which presumably was intended for a graphic depiction of the column on which the instrument was supposed to be mounted. The drawing of a column on fol. 113v, which appears below the text's colophon, appears to be based on a mistaken

\footnotetext{
${ }^{24}$ Zepeda, The First Latin Treatise (note 15), p. 85, points to the comet of 1264 as a potential factor in occasioning the treatise. One must, however, consider the possibility that the mention of this comet in the colophon was due to someone other than Guillaume.
} 
interpretation of the gloss next to it (see below) and so is unlikely to be germane to Guillaume's original work. ${ }^{25}$

With perhaps one exception, the glosses are all written in the same hand as the main text, which indicates that they were already included in the exemplar used by this scribe. Owing to their uniform appearance in the present manuscript, their history is difficult to unravel. The possibility that the glosses to the Tractatus super armillas accumulated over several stages between the original date of completion (10 November 1264) and the execution of the Fermo manuscript (before 1293) seems far from remote. ${ }^{26}$

\section{Guillaume's instrument}

There does not appear to be any other text from medieval Europe that describes the construction of an armillary instrument at a level of technical and practical detail comparable to Guillaume des Moustiers' Tractatus super armillas and its glosses. For one thing, the text is unusual for the attention it devotes to the instrument's dimensions. Right at the beginning, we learn that the two rings representing the ecliptic (3 in Fig. 1) and solstitial colure (4) ought to have a diameter of at least 14 inches and a width of one inch. ${ }^{27}$ Assuming the length of an old Parisian foot or pied du roi of roughly $32.5 \mathrm{~cm},{ }^{28}$ this would indicate minimum values of $c .2 .7 \mathrm{~cm}$ for the width and $c .37 .9 \mathrm{~cm}$ for the diameter. The mobile ring inside the ecliptic (2) must be cut from a plate of high-quality brass, which ideally has been 'hammered and

\footnotetext{
${ }^{25}$ See note 43.

${ }^{26}$ In one instance ( $F$, fol. 113 r, right margin), the content of one gloss is repeated in the context a second gloss directly below it, suggesting that the glosses in the Fermo manuscript are the result of successive stages of accretion.

${ }^{27} \mathrm{~F}$, fol. $110 \mathrm{r}$.

${ }^{28}$ Jan Gyllenbok, Encyclopaedia of Historical Metrology, Weights, and Measures, vol. 2 (Cham: Birkhäuser, 2018), p. 1091.
} 
remelted no more than four times' ${ }^{29}$ It should be at least one inch wide, as with the surrounding rings, and at least 12 inches in diameter. Its thickness is given as half a barleycorn, which is here regarded as the thickness necessary to prevent the ring from bending all too easily. ${ }^{30}$

Guillaume painstakingly describes the degree scales for ecliptic longitude and latitude that must be engraved on the surface of two of the inner rings ( 3 and 2 in Fig. 1). In the case of the ring carrying the longitudinal degrees (3), he deems it important to mark the degrees on the inside as well as the outside, to ensure that the two adjacent rings ( 2 and 5) can be moved to the required position with equal ease. Both sides of this scale feature divisions for all 360 degrees of the zodiac, which on a diameter of $c .37 .9 \mathrm{~cm}$ (as above) would be spaced by approximately $3.3 \mathrm{~mm}$. The middle of this scale is further adorned with the names and ordinal numbers of the twelve signs of the zodiac, while the 30 degrees allotted to each sign are counted in steps of $5 .{ }^{31}$

The author of the Almagesti minor had altered Ptolemy's original design by replacing the innermost ring (1) with an alidade or rule. ${ }^{32}$ Guillaume reinstates the ring and goes into an unprecedented amount of detail on how to manufacture and fasten it inside the ring carrying the latitude scale (2). This inter alia involves the use of a lathe to carve out the inner surface of the surrounding ring, thereby enabling the innermost ring, which is made from the same brass plate, to fit snugly inside the cavity. ${ }^{33}$ Besides carrying two sighting vanes with

\footnotetext{
${ }^{29} \mathrm{~F}$, fol. 110v: 'Et fiat hec armilla interior de lamina simplici boni auricalci, que sit quater ad plus malleata et recocta'.

${ }^{30} \mathrm{~F}$, fol. 110v: 'Et spissitudo eius quasi medietas grani ordei, hoc est, ut sit bone spissitudinis et ut aliquantulum sit ridigda, ne deforis torqueatur'.

${ }^{31} \mathrm{~F}$, fol. $111 \mathrm{r}-\mathrm{v}$.

32 Almagesti minor, V.1, ed. by Zepeda (note 15), p. 332, 11. 51-54.

${ }^{33} \mathrm{~F}$, fols. $110 \mathrm{v}-111 \mathrm{r}$ : 'Deinde cavetur armilla prior per tornum in una eius superficierum laterali. Et fiat cavatura illa intrinsecus latior quam extrinsecus [ms. intrinsecus]. Deinde aptetur armilla secunda quatinus possit illam cavaturam subintrare. Hoc modo circinetur armilla minor secundum quantitatem illius cavature. Deinde
} 
apertures, the innermost ring will also come with two protruding 'tongues' (lingulae), which are there to indicate the degrees shown on the surrounding ring. ${ }^{34}$ One of the glosses instead speaks of a single 'pointer' (almuri) and further mentions that a little spike (aculeus) standing out from each of the vanes will make it easier to find the apertures drilled into their surfaces. ${ }^{35}$

In accordance with the language used in the Almagesti minor,${ }^{36}$ Guillaume refers to the meridional ring (6) as the instrument's 'seat' (sedes), pointing out that it must be fixed precisely in the plane of the meridian. To this end, he mentions three different methods of determining the north-south direction: with a magnetic compass, with an astrolabe, or by means of 'a shadow entering and exiting a circle drawn on a plane surface, with a perpendicularly erected stylus in the middle' ${ }^{37}$ This is an allusion to the so-called 'Indian circle method' of finding directions, which is already described in Vitruvius's De

dividetur per 12 partes equales et dimittantur sex denticuli ex utrimque, ita quod denticuli ex una parte non indirecto sint denticulorum alterius partis. Et residuum limetur secundum cavaturam predictam. Sed sit in medio earum, ut possit hec armilla infra cavaturam predictam retineri sicut cooperculum pixidis per denticulos suos. Hoc modo abscindatur, scilicet armilla prior, in 12 partibus secundum distantiam denticulorum illorum, ut denticuli subintrent cavaturam predictam et non possit aliqua armilla ab armilla egredi, sed maneat utraque armilla in superficie una semper. Deinde obturentur abscisiones et fiet duarum armillarum superficies una. Et ita volvatur una infra reliqua'.

${ }^{34} \mathrm{~F}$, fol. $111 \mathrm{r}$ : 'Post hoc aptabis cum foraminibus suis in locis oppositis super armillam minorem et promineant etiam due lingule que possint gradus huius armille numerare'.

${ }^{35} \mathrm{~F}$, fol. 110 r (right margin): 'Interior circulus defert pinnulas cum almuri. Item super pinnas emineat aculeus, ut foramina citius et rectius videantur. Item obturantur fenestre huius circuli tenticulis metallinis, que cum clavo perpetue firmabuntur'.

${ }^{36}$ Almagesti minor, V.1, ed. by Zepeda (note 15), p. 334, 11. 59-63.

${ }^{37} \mathrm{~F}$, fol. 112 r: 'Linea meridiei queratur per umbram ingredientem circulum factum in plano et egredientem stillo immediate perpendiculariter erecto, vel queratur meridiei linea per adama<n $>$ tem vel astralabium'. More detailed descriptions of the circle-method and of a floating magnetic compass are supplied in glosses on fol. 112r (left margin) and fol. 112v (left margin). For a widely copied account of how to find the four directions with the help of an astrolabe, see pseudo-Māshā'allāh, On the Astrolabe, vol. 4, Practica, ed. and trans. by Thomson (note 7), pp. 174-83 (c. 19). 
architectura $(1.6 .6-7,12) .{ }^{38}$ Guillaume makes a significant addition to Ptolemy's design by surrounding the meridional ring with a seventh ring, the 'circle of altitude' (circulus altitudinis), which revolves around the zenith and nadir marked on the former. The two upper quadrants of this 'circle' will be equipped with a degree scale, making it a tool capable of measuring the altitude of any object above the horizon. Its position relative to the meridional ring, moreover, will give an indication of the object's azimuth. ${ }^{39}$

Rather than being placed directly on the ground, the meridional ring or 'seat' rests on a pedestal (pes) approximately two palms in height, high enough 'to allow the observer freely to place his head under' the instrument and look through the openings on both sighting vanes as well as to discern the corresponding degrees on the latitude scale. ${ }^{40}$ Guillaume next mentions a four-foot tall column, solid enough to withstand stormy winds and the weight applied by the observer. It carries a horizontal plate on which the meridian line is inscribed. ${ }^{41}$ A gloss further clarifies its role, informing us that the plate is emblazoned with two diameters representing the four cardinal directions. At their junction, there will be a slot in which to fasten the aforementioned pedestal holding the meridional ring. ${ }^{42}$

\footnotetext{
${ }^{38}$ Vitruvius, On Architecture: Books I-V, ed. and trans. by Frank Granger (Cambridge, MA: Harvard University Press, 1931), pp. 58-59 (bk. 1, ch. 6.6-7), 64-65 (bk. 1, ch. 6.12).

${ }^{39} \mathrm{~F}$, fol. $112 \mathrm{v}$ : 'Fiat etiam circulus altitudinis circa istam sedem que super cenit capitum et punctum oppositum revolvatur et dividantur per gradus due quarte eius superiores ad accipiendas altitudines, cum necesse fuerit, et qui etiam circulus erit loco omnium azimut'. A similar type of exterior ring appears to have characterized Ptolemy's meteoroscope, effectively a more elaborate version of his armillary instrument. See Rome, 'L'astrolabe' (note 5), pp. 136-149. I am not aware of any evidence that the meteoroscope was known in thirteenth-century Latin Europe.

${ }^{40} \mathrm{~F}$, fol. $112 \mathrm{r}$ : 'Et sit pes sustentans hanc armillam fortis et altitudinis quasi duorum palmorum, ut possit libere considerator caput supponere et aspicere foramina pinnarum predictarum cum gradibus'.

${ }^{41} \mathrm{~F}$, fol. $112 \mathrm{r}$ : 'In loco autem altissimo erigatur perpendiculariter et firmiter columpna 4 pedum non formidans aeris tempestatem nec consideratoris cancellationem, in cuius aera [sic] superiori sit diameter representans certissime lineam meridiei per quam sedes collocetur'.

${ }^{42} \mathrm{~F}$, fol. 112r (right margin): 'Hec columpna firmiter collocata, in cuius summitate lapis duabus dyametris insculptus 4 partes mundi ostendentibus collocetur, armillas sustinebit. Et in confinio diametrorum infigatur
} 
Between this gloss in the right margin and the main text to the left, the scribe left an empty space that appears to have been the intended location of a drawing. Rather than appearing in this space, a column is drawn in the bottom half of fol. $113 \mathrm{v}$, directly underneath the colophon. It is accompanied by another gloss, whose text appears to have been rendered incoherent by scribal corruption or line-skips in the copying process. According to the text in its present state, the column depicted next to it

must be made of brass [and] fastened on [!] a stone plate [lapis], which contains the four parts of the world and firmly placed with the help of cement or lead atop a column made of stone or wood, leading up to [usque ad] a round aperture, namely A. And from this aperture the meridian line will emerge [exiet] when the seat of the rings is considered [in examinatione sedis armillarum]. And in the elongated aperture there will be a copper nail fixing the seat of the rings in perpetuity, such that it cannot totter, nor vacillate, nor be affected by the weather [aeris abhorrere]. Also, around the base of the stone column there should be steps, round of shape, and around the steps that go around the base there should be wooden stakes [vallum ligneum] on which the observer can support himself, such that he can, when he wishes, securely straighten himself up and bend down and withdraw and support himself with his hand or back. ${ }^{43}$

cavilla cuprea et concava, in cuius concavitate pes sedis, clavo in foraminibus pedis et caville concave apposito, includatur'.

${ }^{43} \mathrm{~F}$, fol. $113 \mathrm{v}$ (bottom right margin): 'Ista cassa sive columpna debet fieri de auricalco firmata in lapide continente 4 partes mundi et fortiter situatuo per cementum vel plumbum supra columpnam lapideam vel ligneam usque ad foramen rotundum, scilicet $\mathrm{A}$, et in illo foramine exiet linea meridiei in examinatione sedis armillarum. Et in foramine oblungo erit clavis cupreus firmans sedem armillarum in eternum, ita quod non possit titubare [ms. titulare], neque vacillare, neque aeris abhorrere. Item circa basim columpne lapidee $\operatorname{si}<\mathrm{n}>\mathrm{t}$ gradus rotundici et circa gradus circumeuntes basim sit vallum ligneum ad quod se appodiat considerator, ut cum voluerit possit se erigi secure et incurvari et retrahi et appodiari per manum vel per dorsum'. 
The accompanying drawing indicates the positions of the round aperture A and the oblong aperture above it, but in doing so places them on the columnar shaft rather than on a horizontal plate, where one would expect them to be if their purpose was to help secure the meridional ring. This suggests that the drawing is some later scribe's attempt to interpret the gloss, which presumably got displaced in the course of transmission and originally would have accompanied Guillaume's reference to the four-foot tall column.

\section{Observation and its pitfalls}

In the Almagesti minor, the description of the armillary instrument is followed by a brief account of how to use its different components to measure ecliptic longitudes. ${ }^{44}$ One basic option was to begin observations during daylight and use the known longitude of the Sun to find the longitude of the Moon, which could then serve as a reference point for night-time observations of stellar and planetary positions. Alternatively, one could skip the Sun's degree and begin observations during night-time, provided one knew the longitude of an identifiable fixed star. In either scenario, the ring moving on the convex surface (5 in Fig. 1) of the ecliptic ring (3) will be placed over the known degree of longitude, after which it (i.e., ring 5) will be brought into alignment with the Sun or star in question. Subsequently, the ring moving along the concave surface of the ecliptic ring (2) and the sighting vanes on the innermost ring (1) will both be brought into alignment with the celestial body whose position is sought. Guillaume expands on the Almagesti minor's account with some additional variants of operation, which include the option of using the known position of the Sun to derive the position of Venus, if it is seen during daytime, and then proceed with Venus's longitude as the reference point for night-time observations. Knowing the position of the Sun is here described as a matter of using computational tables to find its true longitude together with the

\footnotetext{
${ }^{44}$ Almagesti minor, V.1, ed. by Zepeda (note 15), pp. 334-36, 11. 66-93.
} 
'motion of the eighth sphere', which must be added. ${ }^{45}$ It is hence clear that Guillaume presupposed the use of some variant of the Toledan Tables, as was standard in thirteenthcentury Europe. ${ }^{46}$

The option of finding the position of one star from the known longitude of another receives some further attention in a gloss on fol. 112v, which uses the example of the star Alramech (i.e., Arcturus or $\alpha$ Boo) being located at $11 ; 30^{\circ}$ Libra.$^{47}$ This is a rather low estimate of its longitude, which historically would have been correct close to the year AD 1090. It seems possible, however, that the glossator confused Alramech with the similar sounding star Alchimech (i.e., Spica or $\alpha$ Vir), which in copies of John of London's aforementioned star list for 1246 appears in a line immediately above or below the former star, at precisely $11 ; 30^{\circ}$ Libra. $^{48}$

Guillaume's main text closes by mentioning some computational uses of the armillary instrument that appear neither in Ptolemy's original account nor in the Almagesti minor: finding the solar declination, the co-culminating degree (or mediation) of a star, 'and other properties that arise for them from the motions of separate [bodies]' ${ }^{49}$ The glosses add some

\footnotetext{
${ }^{45} \mathrm{~F}$, fol. $113 \mathrm{r}$ : 'Equabis Solem per tabulas certissime ad horam in qua volueris considerare. Et addes ei motum octave spere illius temporis et istum locum Solis invenies. Locum Lune ut predictum est invenias, vel locum Veneris, si possibile fuerit, cum simul cum Sole apparuerit super terram, scilicet volvendo armillam extrinsecam super locum Solis et volvatur totum instrumentum ad Solem donec ista armilla et zodiacus sese obumbrent. Deinde volvatur armilla intrinseca et pinne ad Lunam vel Venerem et habebitur locus earum, si fuerint sine diversitate aspectus in longitudine'.

${ }^{46}$ A central hallmark of these tables was their use of sidereal longitudes, which made it necessary to add or subtract the so-called 'equation' of the eighth sphere to arrive at a planet's tropical longitude. See Pedersen, The Toledan Tables (note 7); Samsó, On Both Sides (note 4), pp. 719-34; José Chabás, Computational Astronomy in the Middle Ages: Sets of Astronomical Tables in Latin (Madrid: CSIC, 2019), pp. 47-75.

${ }^{47} F$, fol. 112v (right margin): 'Verbi gratia, Alramech, que est in Libra XI gradus et 30 minuta. In tali puncto super zodiacum debet stella dicta situari'.

${ }^{48}$ See Kunitzsch, Typen (note 7), p. 42; Pedersen, The Toledan Tables (note 7), IV, p. 1503.

${ }^{49} \mathrm{~F}$, fol. 113v: 'Declinatio Solis, gradus cum quo stella mediat celum, et alie proprietates que accidunt eis ex motibus diversorum, hec autem omnia et plurima per ipsas armillas cognoscuntur'.
} 
substance to these extremely concise remarks by explaining how to determine stellar mediations and solar declinations. To find a star's co-culminating degree, one simply moves the sighting vanes of the innermost ring ( 1 in Fig. 1) from the star itself to the meridional ring (6) to then look for the degree on the ecliptic ring (3) that is being intersected by the meridional ring at this instance. In a subsequent step, the vanes can also be used to gauge the altitude of the star at its culmination. ${ }^{50}$ Once the ecliptic degree of the Sun has been aligned with the meridional ring, it will be possible to use the same ring to measure the solar declination, provided one knows which point on its surface corresponds to its intersection with the celestial equator. ${ }^{51}$

The account of the armillary instrument in the Almagesti minor closed with a brief warning, according to which the Moon's measured ecliptic coordinates will be affected by errors corresponding to its parallax in longitude and latitude. ${ }^{52}$ Guillaume's text expands on this problem by offering a handy method of using the rings on the armillary instrument to determine empirically whether the Moon is subject to any longitudinal parallax. It is based on

\footnotetext{
${ }^{50} F$, fol. 113v (left margin): 'Gradus cum quo stella mediat celum sic scitur. Sed prius nota quod in duobus locis ipsius zodaici venit stella cum gradu zodiaci cum quo mediat celum, scilicet in Cancro et in Capricorno, sive in coluro per solsticia transeunte. De primo sic. Inventa stella per pinnulas vide quem gradum zodiaci secat circulus ferens pinnulas. Ille est gradus stelle. Tunc verte pinnulas subtus partem circuli sedis, qui est circulus meridiei, et tunc vide quis gradus zodiaci est secatus a circulo meridiano, vel sub circulo meridiei. Et ille est gradus cum quo stella venit ad meridiem. Item pinnule ostendent quantum stella potest ascendere in meridie, et hoc altitudo stelle nuncupatur. Et cum vis hoc scire, verte pinnulas versus polum quam propius poteris. Et gradus qui magis appropinquabit polum sub circulo sedis erit ipsius stelle gradus altitudinis'.

${ }^{51} F$, fol. 113v (left margin): 'Si vis scire declinationem Solis, pone circulum Solis in directo circuli meridiani, qui sedes appellatur, et tunc in sede nota equinoctialem et ab illa parte incipes computare ascendendo, si utile fuerit, vel descendendo'.

${ }^{52}$ Almagesti minor, V.1, ed. by Zepeda (note 15), p. 336, 11. 90-93. One of the most lucid and influential explanations of parallax available in thirteenth-century Europe was that contained in c. 27 of al-Farghān̄̄'s Elements of Astronomy, which was available in translations by John of Seville and Gerard of Cremona. See $A l$ Farghani Differentie, ed. by Francis J. Carmody (Berkeley, CA: n.a., 1943), pp. 45-46; Alfragano (Al-Fargānī): Il 'Libro dell'aggregazione delle stelle', ed. by Romeo Campani (Città di Castello: Lapi 1910), pp. 162-64.
} 
the realization that this parallax reaches zero at points where the ecliptic is intersected at right angles by a vertical or great circle passing through the zenith. Applied to the rings of the instrument, this means that the ring indicating the ecliptic longitude of the Moon (ring 2 or 5 in Fig. 1), and aligned with the Moon's observable position, must be capable of being coplanar with the altitude ring that revolves around the zenith and nadir. With other words, the two rings must be found together 'in one surface without cutting each other. But if they cut each other, the longitudinal parallax of the Moon will be in the altitude circle's direction of slant' 53

Guillaume adds that the alignment corresponding to zero parallax happens twice each natural 24-day day, once when the Moon is below the horizon (and hence unobservable) and once when it is above. ${ }^{54}$ His remark once again presupposes the presence of a mobile altitude ring added to Ptolemy's design, which can be turned to represent any great circle through the zenith. A different situation would arise if the armillary instrument were reduced to its original six rings, with the meridional ring serving as the outermost ring. In such a configuration, an alignment of rings capable of showing zero longitudinal parallax would require the Moon not only to be on the meridian (as is indeed the case twice every 24 hours), but also precisely at the beginning Cancer or Capricorn, which are the ecliptic degrees the meridian cuts at right angles. A clear awareness of this requirement is shown by the glossator, who points out that

\footnotetext{
${ }^{53} \mathrm{~F}$, fol. $113 \mathrm{r}$ : 'Scietur autem quando non est Lune diversitas in longit<udine> per armillam intrinsecam vel extrinsecam et circulum altitudinis, qui volvitur circa sedem super cenit capitum et punctum ei oppositum. Quando scilicet, una armilla posita super locum Lune, cum revolvitur cum toto instrumento ad Lunam, si fiat vel stat in superficie circuli altitudinis et eadem hora, hoc est, si circulus altitudinis et altera armilla alta similiter posita super locum Lune possint fieri in hora considerationis in superficie una absque eo quod se intersecent. Quod si se intersecent, erit Lune diversitas longitudinis ad partem ad quam declinat circulus altitudinis'. ${ }^{54} \mathrm{~F}$, fol. $113 \mathrm{r}$ : 'Videas ergo quod Luna fiat sine diversitate aspectus in longitudine, quod bis fiet in omni die naturali, semel sub terra, sed tunc non videtur, et semel super terram. Et hoc erit semper cum armilla posita super locum eius transierit per cenit capitis'.
} 
when the Moon is in the direction of the circle called 'seat' or 'circle of the meridian', it always has a parallax [in longitude], except for two places, namely, when it is in Cancer or the sign opposite. Only in these two places is there no parallax of the Moon. ${ }^{55}$

This statement opens a particularly long gloss that gives the impression of having been fused together from several formerly independent comments on the topic of lunar parallax. It mentions both longitudinal and latitudinal parallax and suggests that special tables will be required to account for these factors and correct the observed position of the Moon. ${ }^{56}$ Parallax in latitude is not an issue Bishop Guillaume's main text explores in any detail, other than by remarking that it can be disregarded if one's sole concern is to use the Moon's longitude as a reference point for stellar positions. We are nevertheless told that operations based on the lunar position become more reliable (certius) when the Moon is on the ecliptic, which may perhaps evince an incorrect assumption according to which zero ecliptic latitude equals zero latitudinal parallax. It is at any rate striking that Guillaume makes a similar remark about Venus ('Venus is good to operate with when it is on the ecliptic'), which he then follows up

\footnotetext{
${ }^{55} \mathrm{~F}$, fol. $113 \mathrm{r}$ (right margin): 'Nota cum Luna fuerit in directo circuli qui sedes appellatur sive circulus meridiei, semper habet diversitatem aspectus, exceptis duobus locis, scilicet cum est in Cancro et in signo opposito. In hiis duobus locis solum nulla est diversitas Lune aspectus'.

${ }^{56} \mathrm{~F}$, fol. 113r (right margin): 'Semper oculus dicit Lunam esse longius quam sit. Et item semper dicit esse inferius quam sit. Ideo cavendum est diversitatem aspectus in latitudine. Et cum sic est debet queri in tabulis diversitatis aspectus lune et tantum addi motui lune sumpto per armillas. Et si vis scire quando est diversitas pone circulum altitudinum, qui est super cenit capitum, et fac transire per gradum Lune inventum in zodiaco. Et si secet eum ortogonaliter, scilicet zodiacum et gradum Lune, nulla erit diversitas in longitudine. Si autem non secit ortogonaliter, est diversitas aspectus Lune in longitudine. Et hanc quere in tabulis, quia alibi nequit reperiri'. On the method of correcting for the Moon's change in parallax during observations with the armillary instrument, see Evans, The History (note 5), pp. 251-54.
} 
with 'because its parallax is not as great as the Moon's'. ${ }^{57}$ The latter statement implies that, in Guillaume's opinion, the parallax of Venus was small, but not entirely negligible. Such a position would have been perfectly consistent with the astronomical system of Ptolemy, who placed Mercury and Venus below the Sun and assigned to the latter a maximum (horizontal) parallax of $0 ; 2,51^{\circ} .58$

While parallax is the only source of observational error the main text brings to the reader's attention, the glosses go much further in this regard. One of them admonishes us to avoid taking a celestial body's position when it is too close to the horizon, 'because every translucent or light-emitting body is scattered by dispersed vapours and thus it is inevitable that it will sometimes be seen elsewhere than where it is' ${ }^{59}$ This appears to be an allusion to the phenomenon of atmospheric refraction, which was prominently described in Alhacens's De aspectibus. According to Alhacen (or Ibn al-Haytham), measuring the declination of a celestial body with the help of an equatorial armillary (related to but not identical with the instrument under discussion here) will show that its apparent polar distance becomes greater as it approaches the local zenith compared to when it is seen just above horizon. ${ }^{60}$

\footnotetext{
${ }^{57} \mathrm{~F}$, fol. $113 \mathrm{r}-\mathrm{v}$ : 'De diversitate autem aspectus in latitudine non est curandum quantum ad accipiendum loca stellarum fixarum per locum Lune motum. Per Venerem autem bene operabitur cum ipsa fuerit in ecliptica, quia non est ei tanta diversitas aspectus sicut Lune. Verumtamen cum Luna certius operabitur cum fuerit in ecliptica. Si aliquis planetarum verissime secundum punctum notus non fuerit super terram, per stellam fixam verissime notam erit operandum'.

${ }^{58}$ Almagest V.18, trans. by Toomer (note 3), p. 265.

${ }^{59} \mathrm{~F}$, fol. $112 \mathrm{v}$ (left margin): 'Si fuerit aliquod corpus cuius locus debeat investigari per armillas, caveat considerator ne sit stella nimis vicina orizonti, quia omne corpus dyaphanum sive luminosum a vaporibus resolutis disgregatur, et sic de neccessitate et sic alibi quam fuerit quandoque videbitur'.

${ }^{60}$ Alhacen, De aspectibus 7.4.28-29, ed. and trans. by A. Mark Smith, Alhacen on Refraction, 2 vols. (Philadelphia: American Philosophical Society, 2010), I, pp. 64-66; II, pp. 270-71. See A. Mark Smith, 'Ptolemy, Alhacen, and Ibn Mu'adh and the Problem of Atmospheric Refraction', Centaurus, 45 (2003), 10015 .
} 
One conceivable reaction to this state of affairs would have been to recommend limiting observations with the armillary instrument to those moments when the amount of refraction approaches a minimum, which is the case when the celestial body is on the meridian. Yet the same glossator expressly warns against this approach. According to him, the star in question should not be too close to the meridian, either, since its apparent motion - presumably its change in altitude - slows down in this area of the observable heavens. ${ }^{61}$ An observer who wishes to operate 'securely and firmly' is called upon to observe the body of the star at different places, such that he can obtain the truth. He also ought to have with him a companion through whose testimony and approbation a judgement of the observations shall be made. ${ }^{62}$

In this remarkable passage, the glossator recommends inferring the longitude of a celestial body from multiple observations made at different times of the night, which presumably were meant to correspond to equivalent distances from the meridian. We are told, moreover, that the observer should work in tandem with a collaborator, whose testimony will provide further assurance that the measurements were carried out correctly. The former point receives additional emphasis in a second annotation, which states that the observer 'ought to make multiple observations and at several different hours and times. He also ought to observe the star in different places before daring to make a judgment as to its position and lodging' ${ }^{63}$

\footnotetext{
${ }^{61} \mathrm{~F}$, fol. $112 \mathrm{v}$ (left margin): 'Item caveat iterum ne sit corpus stelle vicina meridei, eo quod ibi per longum spacium videbitur commorari'.

${ }^{62} \mathrm{~F}$, fol. 112v (left margin): 'Propter hoc, qui secute et firmiter voluerit considerare corpus stelle, in diversis locis consideret, ut habeat veritatem. Item secum habeat considerator consortem per cuius testimonium et assensum fiat iudicium de consideratione acceptorum'.

${ }^{63} \mathrm{~F}$, fol. $113 \mathrm{r}$ (right margin): 'Considerat [sic] pluries et pluribus horis et temporibus diversis. Consideret stellam et in diversis locis prius quam de situ et eius mansione audeat iudicare'.
} 
This theme of safeguarding against observational error resurfaces in a gloss that addresses a host of possible factors that might negatively affect the result of one's measurement. When it comes to the observer's own role, the most significant shortcomings to be borne in mind are: ${ }^{64}$

1. ignorance

2. weakness of the body, such as impaired eyesight

3. laziness

4. distractions caused by intoxication or stress.

On the part of the instrument, the following factors must be considered: ${ }^{65}$

1. the instrument may have an insufficient number of rings

2. or, sometimes, too many rings

3. the rings may move (and thereby bring the instrument out of alignment)

4. the degree scales on the innermost rings may be imprecise or faulty.

Numerous further risk factors can arise from the place where the instrument is set up (a parte loci), or from local weather conditions ( a parte aeris), or-so we are told—even from the celestial bodies themselves (a parte corporum supercelestium). 'In carrying out an observation one must therefore be astute, aware, discerning, and watchful' ${ }^{66}$

\footnotetext{
${ }^{64} F$, fol. $112 \mathrm{v}$ (left margin): 'Notandum quod multa impediunt considerationis veritatem. A parte consideratoris erit primo ignorantia, secundo corporis debilitas, ut maxime oculorum hebitudo, tertio pigricia, quarto superfluitas, ut crapule et negociorum'.

${ }^{65} \mathrm{~F}$, fol. $112 \mathrm{v}$ : 'In parte instrumenti sunt cause infinite, ut est paucitas circulorum, et quandoque multitudo, tercio motus armillarum, quarto graduum distinctio cum fractionibus'.

${ }^{66} \mathrm{~F}$, fol. $112 \mathrm{v}$ (left margin): 'A parte loci infinita impedimenta. A parte aeris multa. A parte corporum supercelestium multa. Ideo sit cautus, astutus, prudens, discretus et evigilans in considerando’.
} 


\section{Conclusion}

The Tractatus super armillas written by Guillaume des Moustiers, bishop of Laon, in the year 1264, along with the glosses that accompany it in the only known manuscript, deserves attention for the light it casts on the role of empirical measurement in pre-modern European astronomy. As a thirteenth-century description of a slightly modified version of Ptolemy's armillary instrument, the text goes into an otherwise unattested level of detail concerning its material aspects and the methods of its assembly. Such attention to detail is best explained as reflecting practical experience, perhaps accompanied by a certain degree of experimentation in the instrument's manufacture. Likewise, the remarks on its practical applications seem well-informed and are likely to have been shaped by genuine experience in this area. What becomes especially manifest from this Tractatus and its glosses is that thirteenth-century astronomers in the Latin world were familiar with the difficulties and sources of error that potentially affected attempts to measure ecliptic coordinates of planets and stars, and that they considered means of mitigating against them.

In documenting contemporary awareness in this area, this previously unstudied source hence enriches our knowledge of the empirical side of medieval science and puts certain question marks behind modern accounts that seek to minimize the role of observation in the mathematical astronomy practiced during this period. 


\section{Acknowledgment}

I am very grateful to David Juste and two anonymous referees for Annals of Science for their helpful comments on earlier drafts of this article.

\section{Funding}

The research leading to these results has received funding from the European Union's

Horizon 2020 research and innovation programme under the Marie Skłodowska-Curie grant agreement No 754340 .

\section{Figures}

Figure 1: Ptolemy’s armillary instrument. Source: G. J. Toomer, trans., Ptolemy’s Almagest, rev. ed. (Princeton, NJ: Princeton University Press, 1998), p. 218 